\title{
ANALISIS ROA, ROE, EPS, PER, DAN DER TERHADAP HARGA SAHAM PADA PERUSAHAAN REAL ESTATE YANG TERDAFTAR DI BURSA EFEK INDONESIA PERIODE 2013-2016
}

\author{
Charista Nurul Mafazah \\ Fakultas Ekonomi dan Bisnis, Universitas Nahdlatul Ulama Surabaya \\ e-mail: leecharaleejinki@gmail.com
}

\begin{abstract}
The aim of this research to examine are there impact of ROA, ROE, EPS, PER, and DER as an independent variable whit stock price as dependent variable on 10 real estate companies listed in Indonesia stock exchange and have financial statements in the period 2013-2016 so that the unit of analysis obtained is 40 financial statement list real estate company. The research variable consisted on independent variable in the form of return on asset (X1), return on equity (X2), earning per share (X3), price earning ratio (X4), debt to equity ratio (X5), and stock price (Y) as a dependent variable. Methods of data collection in of this research is the method of documentation. Data analysis technique were use multiple linier regression. Based on the results of regression analysis known that influence of return on asset, return on equity, earning per share, price earning ratio, and debt to equity ratio and simultaneously influence the stock price on the Indonesia stock exchange in period 2013-2016 at 92,8\% while the rest influenced by other variables is not examined in this research. Partially, return on asset and earning per share significantly influence to stock prices, while return on equity, price earning ratio, debt to equity ratio but not significant effect on stock prices.
\end{abstract}

Keywords: stock prices, return on asset, return on equity, earning per share, price earning ratio and debt to equity ratio

\section{PENDAHULUAN}

Persaingan bisnis yang semakin hari semakin ketat saat ini mendorong perusahaan untuk memiliki keunggulan bersaing agar dapat memenangkan persaingan. Oleh karena itu dibutuhkan modal yang cukup untuk menghasilkan keunikan produk agar dapat bersaing dengan perusahaan sejenis.

Modal dapat diperoleh dari mana saja salah satunya dengan menawarkan kepemilikan perusahaan tersebut kepada masyarakat/publik (go public). Pasar modal pada dasarnya adalah pasar yang tidak berbeda jauh dengan pasar tradisional, di mana ada pedagang, pembeli, dan juga ada tawar menawar harga.
Investasi diartikan sebagai pengeluaran atau pembelanjaan penanaman suatu modal atau perusahaan untuk membeli barang-barang modal dan juga perlengkapan produksi untuk menambah kemampuan memproduksi barang dan juga jasa yang tersedia.

Salah satu bidang investasi yang cukup menarik namun berisiko tinggi adalah investasi saham. Saham merupakan surat bukti bahwa kepemilikan atas aset-aset perusahaan yang menerbitkan saham (Tandelilin, 2001). Saham perusahaan publik sebagai komoditi investasi tergolong berisiko tinggi karena sifat komoditasnya sangat peka terhadap perubahan yang terjadi, baik perubahan di luar negeri maupun di dalam negeri, perubahan politik, ekonomi, dan mone- 
ter. Perubahan tersebut dapat berdampak positif yang berarti naiknya harga saham atau berdampak negatif yang berarti turunnya harga saham.

Dalam melakukan analisis dan memilih saham, ada dua analisis atau pendekatan yang sering digunakan, yaitu analisis teknikal dan analisis fundamental (Jumayanti Indah Lastari, 2004). Analisis teknikal adalah suatu metode yang digunakan untuk menilai saham, di mana dengan metode ini para analis melakukan evaluasi saham berbasis pada data-data statistik yang dihasilkan dari aktivitas perdagangan saham, seperti harga saham dan volume transaksi.

Harga saham adalah faktor yang membuat para investor menginvestasikan dananya di pasar modal dikarenakan dapat mencerminkan tingkat pengembalian modal. Pada prinsipnya, investor membeli saham adalah untuk mendapatkan dividen serta menjual saham tersebut pada harga yang lebih tinggi (capital gain).

Pada penelitian ini peneliti akan mengukur pengaruh earning per share (EPS), return on asset (ROA), return on equity (ROE), price earning ratio (PER), dan debt to equity ratio (DER) terhadap harga saham perusahaan real estate.

Kehadiran pasar modal di Indonesia ditandai dengan banyaknya investor yang mulai menanamkan sahamnya dalam industri real estate dan properti. Bisnis real estate dan properti baik residensial maupun komersial menunjukkan perkembangan yang cukup pesat di Indonesia.

Pada penelitian ini peneliti juga menggunakan data laporan keuangan pada perusahaan real estate dan properti dari tahun 2013-2016 yang pada periode tersebut merupakan periode di mana harga saham mengalami kenaikan yang cukup signifikan. Pada penelitian ini menggunakan objek 10 perusahaan real estate yang telah mengeluarkan laporan keuangan 2016 dan mengalami peningkatan dalam hal harga saham.

\section{KERANGKA TEORETIS}

\section{Saham}

Saham adalah surat berharga sebagai bukti penyertaan atau pemilikan individu atau institusi dalam suatu perusahaan (Ang, 1997). Menurut Brigham dan Houston (1999) saham adalah tanda kepemilikan perusahaan, kepemilikan saham biasanya disimbolkan dengan saham biasa (common stock).

\section{Return on Asset (ROA)}

Menurut Brigham dan Houston (2001:90), "Rasio laba bersih terhadap total aktiva mengukur pengembalian atas total aktiva (ROA) setelah bunga dan pajak". Sedangkan menurut Horne dan Wachowicz (2005:235), "ROA mengukur efektivitas keseluruhan dalam menghasilkan laba melalui aktiva yang tersedia; daya untuk menghasilkan laba dari modal yang diinvestasikan”. Return on assets menunjukkan seberapa banyak laba bersih yang bisa diperoleh dari seluruh kekayaan yang dimiliki perusahaan, karena itu dipergunakan angka laba setelah pajak dan (rata-rata) kekayaan perusahaan.

\section{Return on Equity (ROE)}

Bodie dan Marcus (2006) menyatakan bahwa ROE merupakan salah satu dari dua dasar untuk menentukan tingkat pertumbuhan beta perusahaan. Kadang cukup wajar berasumsi bahwa ROE yang tinggi di masa lalu tidak berarti bahwa ROE perusahaan di masa depan juga tinggi. Menurut Kasmir (2008: 204) bahwa hasil pengembalian ekuitas atau return on equity atau rentabilitas modal sendiri merupakan rasio untuk mengukur laba bersih sesudah pajak dengan modal sendiri. 


\section{Earning Per Share (EPS)}

Price earning ratio menggambarkan apresiasi pasar terhadap kemampuan perusahaan dalam menghasilkan laba (Darmaji, 2001:139). Sedangkan menurut Ang (1997: 24), "Price earning ratio merupakan perbandingan antara harga pasar suatu saham dengan earning per share (EPS) dari saham yang bersangkutan".

\section{Price Earning Ratio (PER)}

Price earning ratio menggambarkan apresiasi pasar terhadap kemampuan perusahaan dalam menghasilkan laba (Darmaji, 2001:139). Sedangkan menurut Ang (1997: 24), "Price earning ratio merupakan perbandingan antara harga pasar suatu saham dengan earning per share (EPS) dari saham yang bersangkutan”.

\section{Debt to Equity ratio (DER)}

Debt to equity ratio adalah rasio yang mengukur sejauh mana besarnya utang dapat ditutupi oleh modal sendiri (Darmadji dan Fakhruddin, 2006: 200). Rasio ini menunjukkan komposisi atau struktur modal dari total utang terhadap total modal yang dimiliki perusahaan.

\section{Pengaruh ROA terhadap Harga Saham}

Return on assets (ROA) menurut pandangan Brigham dan Houston (2006:109) "adalah mengukur tingkat pengembalian atas total aktiva." Semakin besar ROA menunjukkan kinerja perusahaan semakin baik, karena return semakin besar. Dengan adanya return yang semakin besar maka akan menarik minat investor untuk menanamkan modalnya pada perusahaan tersebut sehingga selanjutnya akan berdampak pada ke- naikan harga saham karena bertambahnya permintaan terhadap saham perusahaan tersebut.

Oleh karena itu, secara teoretis ROA memiliki pengaruh yang positif terhadap harga saham. Pernyataan tersebut diperkuat oleh hasil penelitian E. Amaliah Itabillah (2011) bahwa ROA tidak mempunyai pengaruh negatif yang signifikan terhadap harga saham. Dari uraian di atas maka dapat disimpulkan hipotesis dalam penelitian ini adalah sebagai berikut.

H1: Return on assets (ROA) berpengaruh dan signifikan terhadap harga saham.

\section{Pengaruh ROE terhadap Harga Saham}

Menurut Chrisna (2011: 34) kenaikan return on equity biasanya diikuti oleh kenaikan harga saham perusahaan tersebut. Semakin tinggi ROE berarti semakin baik kinerja perusahaan dalam mengelola modalnya untuk menghasilkan keuntungan bagi pemegang saham. Dapat dikatakan bahwa perusahaan tersebut dapat menggunakan modal dari pemegang saham secara efektif dan efisien untuk memperoleh laba.

Dengan adanya peningkatan laba bersih maka nilai ROE akan meningkat pula sehingga para investor tertarik untuk membeli saham tersebut yang akhirnya harga saham perusahaan tersebut mengalami kenaikan. Hasil penelitian Cerpen Naibaho (2010) menunjukkan bahwa return on equity (ROE) berpengaruh terhadap harga saham.

$\mathrm{H} 2$ : Return on equity (ROE) berpengaruh dan signifikan terhadap harga saham.

\section{Pengaruh EPS terhadap Harga Saham}

Earning per share (EPS) merupakan salah satu informasi akuntansi yang menunjukkan besarnya keuntungan bersih per lembar saham 
yang mampu dihasilkan perusahaan. Darsono dan Ashari (2005:57) mengatakan bahwa "Earning per share (EPS) adalah mengukur besarnya pengembalian modal untuk setiap satu lembar saham."

EPS yang tinggi menunjukkan bahwa tingkat efisiensi dan efektivitas pengelolaan perusahaan baik. Pemegang saham biasa dan calon pemegang saham sangat tertarik akan EPS, karena hal ini akan menggambarkan jumlah rupiah yang diperoleh untuk setiap lembar saham. 21 Peningkatan EPS menandakan bahwa perusahaan berhasil meningkatkan taraf kemakmuran investor, dan hal ini akan mendorong investor untuk menambah jumlah modal yang ditanamkan pada perusahaan.

Pernyataan tersebut diperkuat oleh hasil penelitian dari Siti Marfuatun dan Iin Indarti (2012) dan E. Amaliah Itabillah (2011) bahwa EPS berpengaruh positif dan signifikan terhadap harga saham. Dari uraian di atas dapat disimpulkan hipotesis dalam penelitian ini adalah sebagai berikut.

H3: Earning per share (EPS) berpengaruh dan signifikan terhadap harga saham.

\section{Pengaruh Hubungan PER terhadap Harga Saham}

PER menunjukkan seberapa besar bagi investor bersedia untuk membayar persatuan mata uang dari keuntungan yang dilaporkan dan inilah yang terjadi instrumen yang cukup penting. Menurut Husnan (2006:76): apabila pasar modal efisien, PER akan mencerminkan laba perusahaan, semakin tinggi rasio ini, makin tinggi pertumbuhan laba yang diharapkan pemodal. Kondisi ini tentu saja akan membuat ketertarikan tersendiri bagi investor. Price earning ratio merupakan suatu rasio yang lazim dipakai untuk mengukur harga pasar (market price) setiap lembar saham biasa dengan laba per lembar saham. Ukuran ini melibatkan suatu jumlah yang tidak secara langsung dikendalikan oleh perusahaan harga pasar saham biasa. Rasio harga/laba mencerminkan penilaian pemodal terhadap pendapatan di masa mendatang. (Simamora, 2000: 531).

Menurut Husnan (2001) secara fundamental rasio ini diperhatikan oleh investor dalam memilih saham karena perusahaan yang mempunyai nilai PER yang tinggi menunjukkan nilai pasar yang tinggi pula atas saham tersebut, sehingga saham tersebut akan diminati oleh investor dan hal ini pada akhirnya akan berdampak pada kenaikan harga saham.

\section{Pengaruh DER terhadap Harga Saham}

Debt to Equity Rasio (DER) menurut Husnan (2006: 70) "merupakan salah satu rasio keuangan yang mengukur seberapa besar kemampuan perusahaan dalam melunasi utang dengan modal yang dimiliki." Rasio ini menunjukkan perbandingan antara dana pinjaman dan modal dalam upaya pengembangan perusahaan.

Fara dharmastuti (2004) menyatakan bahwa: DER yang tinggi menunjukkan bahwa perusahaan sangat bergantung pada pihak luar yang mendanai kegiatan usahanya sehingga beban perusahaan juga meningkat. DER yang tinggi cenderung menyebabkan harga saham menurun karena jika perusahaan memperoleh laba, perusahaan cenderung menggunakan laba tersebut untuk membayar utangnya dibandingkan membagi dividen. Perusahaan dengan utang yang tinggi akan bangkrut, akibatnya investor akan menghindari saham-saham dengan nilai laba yang rendah yang akhirnya akan menurunkan harga saham yang akan berimbas pada harga saham.

Pernyataan tersebut diperkuat oleh hasil penelitian dari E. Amaliah Itabillah (2011) bahwa DER berpengaruh negatif secara parsial terhadap 
harga saham. Dari uraian di atas maka dapat disimpulkan hipotesis dalam penelitian ini adalah sebagai berikut.

H5: Debt to equity ratio (DER) berpengaruh terhadap harga saham.

\section{METODE PENELITIAN}

\section{Sample dan Prosedur}

Pengumpulan data dilakukan dengan menggunakan data sekunder yang diterbitkan dan dipublikasikan oleh BI. Data tersebut dapat diakses melalui www.bi.go.id. Data yang di ambil merupakan data laporan keuangan 10 perusahaan real estate yang terdaftar pada Indonesia stock exchange memiliki laporan keuangan dari tahun 2013-2016. Data-data yang diambil adalah laporan keuangan bulanan perusahaan real estate.

\section{Variabel Penelitian dan Pengukuran}

Dalam penelitian ini jenis variabel yang digunakan adalah variabel independen dan variabel dependen. Variabel independen disebut juga sebagai variabel bebas, di mana variabel tersebut memengaruhi atau yang memengaruhi variabel dependen (variabel terikat). Sedangkan variabel dependen sendiri adalah variabel yang dipengaruhi atau yang menjadi akibat karena adanya variabel bebas. Variabel yang digunakan dalam penelitian ini adalah:

1. return on asset (ROA)

2. return on equity (ROE)

3. earning Per Share (EPS)

4. price earning Ratio (PER)

5. debt to equity ratio (DER)

Kelima variabel tersebut merupakan variabel independen, sedangkan variabel dependen yang digunakan adalah harga saham.

\section{Analisis Regresi Linier Berganda}

Alat yang digunakan dalam perhitungan ini menggunakan SPSS 20, dengan menggunakan model penelitian:

$$
\begin{aligned}
& \mathrm{Y}=\mathrm{a}+\text { â } 1 \mathrm{X} 1+\text { â2 X2 + â } 3 \mathrm{X} 3+\text { â } 4 \mathrm{X} 4 \text { + â } 4 \text { X4 } \\
& + \text { â } 5 \text { X5 +..! }
\end{aligned}
$$

Di mana:

$\mathrm{Y}=$ harga saham

$\alpha=$ konstanta

$\mathrm{X} 1=$ return on asset $(\mathrm{ROA})$

$\mathrm{X} 2$ = return on equity (ROE)

$\mathrm{X} 3$ = earning per share (EPS)

$\mathrm{X} 4$ = price earning ratio (PER)

$\mathrm{X} 5=$ debt to equity ratio (DER)

$\mathrm{e} \quad=$ kesalahan pengganggu

$\beta 1-5=$ koefisien regresi

Pengujian hipotesis yang akan dilakukan dalam penelitian ini ada beberapa tahapan, yaitu dengan menguji secara parsial (T), uji simultan (F), dan uji koefisien determinasi $\left(\mathrm{R}^{2}\right)$.

Uji parsial (T) digunakan untuk menunjukkan seberapa jauh pengaruh variabel independen dengan variabel dependen secara individual. Cara melakukan uji T adalah dengan membandingkan nilai statistik $\mathrm{T}$ dengan nilai Ttabel. Jika nilai statistik $\mathrm{T}>$ nilai Ttabel, maka $\mathrm{H}_{\mathrm{o}}$ ditolak. Jika nilai Tstatistik < nilai Ttabel, maka $\mathrm{H}_{\mathrm{o}}$ diterima.

Uji simultan (F) menunjukkan apakah ada hubungan secara bersama-sama antara variabelvariabel bebas dengan variabel terikat. Cara melakukan uji $\mathrm{F}$ ini yaitu dengan membandingkan nilai $\mathrm{F}$ hitung dan $\mathrm{F}$ tabel.Jika $\mathrm{F}$ hitung > F tabel, maka $\mathrm{H}_{\mathrm{o}}$ ditolak dan menerima $\mathrm{H}_{1}$.

Koefisien determinasi digunakan untuk mengukur seberapa jauh kemampuan model dalam menerangkan variasi variabel dependen. Nilai koefisien determinasi adalah antara 0 dan 1. Nilai $\mathrm{R}^{2}$ yang kecil berarti kemampuan variabel-variabel independen dalam menjelaskan variabel dependen sangat terbatas. Nilai $\mathrm{R}^{2}$ yang mendekati 1 menunjukkan bahwa variabel inde- 
penden member hampir semua informasi yang dibutuhkan untuk memprediksi variabel dependen (Ghozali, 2011:97).

\section{HASIL DAN PEMBAHASAN}

Hasil penelitian ini adalah variabel ROA ( $\beta 1)$ sebesar -113,65 menyatakan bahwa koefisien regresi yang negative yang berarti ROA memiliki hubungan negative dengan harga saham, variabel ROE ( $\beta 2)$ sebesar -1,961 menyatakan bahwa koefisien regresi ROE mempunyai hubungan yang negative terhadap harga saham, koefisien regresi untuk variabel EPS ( $\beta 3$ ) sebesar 19,450 menyatakan bahwa koefisien regresi yang positif berarti EPS mempunyai hubungan yang positif terhadap harga saham, koefisien regresi untuk PER ( $\beta 4)$ sebesar 21,615 menyatakan bahwa koefisien regresi yang positif berarti jika PER berpengaruh positif terhadap harga saham dan koefisien regresi untuk DER ( $\beta 5)$ sebesar 4,273 menyatakan bahwa koefisien regresi yang positif mempunyai hubungan yang positif terhadap harga saham. Secara simultan kelima pembiayaan tersebut memiliki pengaruh terhadap ROE, hal ini sesuai dengan hipotesis lima atau $\mathrm{H}_{5-}$ diterima.

Tabel 4.12

Hasil Uji Regresi Linier Berganda

\begin{tabular}{|cl|l|l|}
\hline \multicolumn{1}{|c|}{ Model } & \multicolumn{1}{|c|}{ B } & sig \\
\hline \multirow{4}{*}{1} & (Constant) & -448.403 & .050 \\
& ROA & -113.648 & .006 \\
& ROE & -1.961 & .901 \\
& EPS & 19.430 & .000 \\
& PER & 21.615 & .000 \\
& DER & 4.273 & .068 \\
\hline
\end{tabular}

Suatu variabel dikatakan berpengaruh apabila nilai signifikan lebih kecil dari 0,05 , dari hasil perhitungan di atas variabel yang memiliki pengaruh signifikan terhadap ROE adalah murabahah dan mudharabah.

Persamaan yang diperoleh dari tabel di atas adalah sebagai berikut.

$$
\begin{aligned}
\mathrm{Y}= & -448,40-113,65 \mathrm{X} 1-1,961 \mathrm{X} 2+ \\
& 19,430 \mathrm{X} 3+21,615 \mathrm{X} 4+4,273 \mathrm{X} 5+\mathrm{e}
\end{aligned}
$$

Persamaan di atas memiliki makna sebagai berikut.

a. Konstan $=-448,40$

Nilai konstan sama dengan $-448,40$ artinya jika nilai x (laporan keuangan yang menjadi variabel independen) sama dengan 0 , maka harga saham sebesar 2,748.

b. $R O A\left(\mathrm{X}_{1}\right)=-113,65$

Nilai tersebut merupakan nilai koefisien regresi variabel $R O A\left(\mathrm{X}_{1}\right)$, terhadap Harga saham. Koefisien bernilai negatif artinya variabel independen memiliki hubungan terbalik dengan variabel dependen. Jika ROA mengalami kenaikan senilai 1, maka Harga saham mengalami penurunan sebesar -113,65.

c. $\operatorname{ROE}\left(\mathrm{X}_{2}\right)=-1,961$

Nilai tersebut merupakan nilai koefisien regresi variabel $\operatorname{ROE}\left(\mathrm{X}_{2}\right)$, terhadap harga saham. Koefisien bernilai negatif artinya variabel independen memiliki hubungan berbalik dengan variabel dependen. Jika pembiayaan ROE mengalami kenaikan senilai 1, maka harga saham mengalami penurunan sebesar $-1,961$.

d. EPS $\left(\mathrm{X}_{3}\right)=19,430$

Nilai tersebut merupakan nilai koefisien regresi variabel EPS $\left(\mathrm{X}_{3}\right)$, terhadap harga saham. Koefisien bernilai positif artinya variabel independen memiliki hubungan searah dengan variabel dependen. Jika pembiayaan EPS mengalami kenaikan senilai 1 maka harga saham juga naik sebesar 19,430. 
e. PER $\left(\mathrm{X}_{4}\right)=21,615$

Nilai tersebut merupakan nilai koefisien regresi variabel PER $\left(\mathrm{X}_{4}\right)$, terhadap harga saham. Koefisien bernilai positif artinya variabel independen memiliki hubungan searah dengan variabel dependen. Jika pembiayaan PER mengalami kenaikan senilai 1 maka harga saham mengalami kenaikan sebesar 21,615.

f. $\operatorname{DER}\left(\mathrm{X}_{4}\right)=4,273$

Nilai tersebut merupakan nilai koefisien regresi variabel DER $\left(\mathrm{X}_{4}\right)$, terhadap harga saham. Koefisien bernilai positif artinya variabel independen memiliki hubungan searah dengan variabel dependen. Jika pembiayaan DER mengalami kenaikan senilai 1 maka harga saham mengalami kenaikan sebesar 4,273.

\section{PEMBAHASAN}

Dari hasil pengujian hipotesis secara simultan yang telah dilakukan hasil penelitian ini menunjukkan bahwa secara simultan terdapat pengaruh antara ROA, ROE, EPS, PER dan DER terhadap harga saham yang terdaftar di IDX pada periode penelitian 2013-2016 hal ini di tunjukkan dengan hasil nilai signifikansi $F$ sebesar $0,000<0,05$ dan nilai $F$ hitung $>F$ tabel di mana 101,43>2,65 dan besarnya pengaruh yang diberikan adalah sebesar 92,8\% dan sisanya $7,2 \%$ dipengaruhi oleh variabel lain yang tidak termasuk dalam penelitian ini.

Hasil pengujian hipotesis secara parsial yang telah dilakukan, variabel independen return on asset (ROA) berpengaruh signifikan terhadap harga saham. Ditunjukkan pula dengan nilai signifikansi $\mathrm{T}$ sebesar $0,000<5 \%$. Tetapi dengan koefisien negative menandakan ada yang berarti ada eror terjadi pada data yang seharusnya berpengaruh positif atau saling keterkaitan. Hal ini terjadi karena pada data periode harga saham dan ROA sama. Berdasarkan dugaan dalam penelitian ini disebutkan bahwa ada pengaruh return on equity (ROE) terhadap harga saham. Dari hasil pengujian hipotesis secara parsial yang telah dilakukan, ternyata diketahui bahwa return on equity (ROE) tidak berpengaruh terhadap harga saham. Ini ditunjukkan dengan nilai signifikan $\mathrm{t}$ sebesar $0,901>0,05$ tetapi mempunyai nilai koefisien negatif yang berarti jika ROE menurun akan membuat peningkatan harga saham.

Variabel independen earning per share (EPS) berpengaruh positif dan signifikan terhadap harga saham dengan ditunjukkan nilai signifikansi $t$ sebesar $0,000<5 \%$. Setelah melakukan uji hipotesis diketahui bahwa price earning ratio (PER) tidak berpengaruh secara signifikan dengan nilai signifikansi $\mathrm{t}$ sebesar $0,000>5 \%$. Dari hasil pengujian hipotesis secara parsial yang telah dilakukan ternyata diketahui bahwa debt to equity ratio (DER) tidak berpengaruh terhadap harga saham, ini ditunjukkan dengan nilai signifikansi t sebesar 0,068 >0,05 dan mempunyai nilai koefisien negatif sehingga jika debt to equity ratio (DER) turun maka nilai harga saham akan naik.

\section{SIMPULAN DAN SARAN}

Berdasarkan analisis data dan pembahasan yang telah dilakukan maka dapat diambil suatu kesimpulan bahwa secara simultan ROA, ROE, EPS, PER, dan DER berpengaruh secara signifikan terhadap harga saham.

Selanjutnya setelah di uji secara individu di ketahui terdapat tiga variabel yang berpengaruh terhadap harga saham dan dua variabel yang tidak berpengaruh. Ketiga variabel tersebut adalah return on asset (ROA), earning per share (EPS), dan price earning ratio (PER). Sedangkan 
untuk variabel yang tidak berpengaruh dengan harga saham adalah return on equity (ROE) dan debt to equity ratio (DER)

Saran pada penelitian ini adalah data harga saham yang digunakan dalam penelitian menggunakan data saham per 31 Desember. Untuk penelitian selanjutnya diharapkan menggunakan data saham harian karena harga saham dapat berubah sewaktu-waktu. Manajemen pada perusahaan real estate sebaiknya memperhatikan tingkat solvabilitas perusahaan, karena aspek ini mempunyai pengaruh yang negatif terhadap harga saham sehingga dapat memperbaiki nilai perusahaan tersebut.

\section{DAFTAR PUSTAKA}

Ang, Robert. 1997. Buku Pintar Pasar Modal Indonesia. Jakarta: Mediasoft Indonesia
Darmaji, Tjiptono dan Hendy M. Fakhrudin. 2006. Pasar Modal di Indonesia Pendekatan Tanya Jawab. Jakarta: Salemba Empat.

Ghozali, Prof. Dr. H. Imam. 2006. Aplikasi Analisis Multivariate dengan Program SPSS. Semarang: Badan Penerbit Universitas Diponegoro.

Indriyanti, Feri. 2006. Pengaruh Rasio Profabilitas Terhadap Economic Rents Rasio Tobins Q pada Perusahaan Manufaktur Go Publik: Skripsi Universitas Negeri Semarang.

Ismail, Hidayat. 2010. Analisis Pengaruh Return on Asset, Debt to Equity Ratio, dan Debt Ratio Terhadap Harga Saham pada Perusahaan Tobacco Manufacturers di Bursa Efek Indonesia. UPN Veteran: Skripsi.

Kamaludin, D.R. Manajemen Keuangan Konsep Dasar dan Penerapannya. Jakarta: Mandar Maju. 